\title{
Female Heads of Households Registered in Korea's Census Registers Between the Seventeenth and Nine- teenth Centuries and Their Historical Significance
}

Kyungran Kim*

\section{Introduction}

Research on women in ancient Korea has mainly been conducted within the scope of the family system, particularly focusing on women's social status in relation to the characteristics of the family order of the time. Bilateral descent was the system of family lineage in traditional Korean society from the Koryŏ dynasty (10th century to 14th century) to the early Chosŏn dynasty (15th century to 16 th century) with a bilateral system, in which the relatives of the father's side and of mother's (wives') side were considered equally important. It has been understood that this bilateral family system led to the establishment of a social structure that enabled women to occupy a relatively high social status. ${ }^{1}$

* Lecturer, Korea University, Seoul, South Korea

1 Martina Deuchler, The Confucian Transformation of Korea: A Study of Society and Ideology (Cambridge: Harvard University Press, 1992); Lee Soon-Gu and Han Heesook, "Chosŏn-sidae Yŏsŏngsa Kwallyŏn Yŏn'gu-ŭi Hyŏhwang-gwa Kwaje (The Current Status and Issues in Studies on Women in the Chosŏn Dynasty)," in Such'on Pak Yŏng-sŏk Kyosu Hwagap Kinyŏm Han'guksahangnonch'ong 1, ed. Such'on Pagyŏngsŏk Kyosu Hwagap Kinyŏm Nonch'ongganhaengwiwŏnhoe (Seoul: T'amgudang, 1992); Mark A. Peterson, Korean Adoption and Inheritance: Case Studies in the Creation of a Classic Confucian Society (Ithaca: East Asian 
In the seventeenth century, however, the family system in traditional Korean society underwent a great change. In the late Chosonn dynasty (17th to 19th centuries), the patrilineal family order became more common, focusing on patrilineal descendants, and as a result, gender discrimination against women was institutionalized and reinforced, particularly in terms of inheritance and ownership of property. Generally, it is understood that as Confucian ideology became widespread, women who had received inheritances equal to their male siblings and had a strong voice in the family until the early Chosŏn dynasty, were forced into lower social status, excluded from receiving inheritances and prohibited from remarrying. ${ }^{2}$

In this way, the discussion on women's status in traditional Korea was limited to the private domain of the family. However, it is important to include women's roles and their function in both the private and public arenas when discussing their social status in traditional Korea. Nevertheless, previous studies have discussed women's status within the confines of the family system, for women in traditional Korea were assumed to have been excluded from the public arena. In fact, women in Chosŏn Korea were fundamentally excluded from directly participating in politics, and ways for women to hold government positions and participate in policymaking or political discussions were almost nonexistent. Women were also legally banned from performing certain social activities. Laws that restricted yangban women (women of the elite class) from going outside their homes or banned them from entering Buddhist temples were stipulated in the Kyŏngguk Taejŏn (The Great Code for Governing the State), the basic code of law in the Chosŏn dynasty. ${ }^{3}$ As a result, people believed that women in traditional Korea were excluded from the public domain

Program Cornell University, 2000).

2 Lee Soon-Gu, "Chosŏnch'ogi Chongbŏbŭi Suyonggwa Yŏsŏngjiwiŭi Pyŏnhwa Propagation of the Chong-pop and Changes in the Status of Women during the early Chosŏn Dynasty)" (PhD diss., Academy of Korean Studies, 1995).

3 Kyŏngguk Taejŏn (經國大典), Criminal Code (刑典), Prohibition Article (禁制條). 
and only played a role within the family. Then, is it true that women in traditional Korea did not play any role in the public arena?

The idea that women's roles were strictly limited to within the family is a widely held view. Yet, in fact, parts of the state administration in Chosŏn Korea required the participation of women. The state wished to grant women public roles, one of which was that of the head of a household. The existence of women as heads of households can be confirmed in the census registers (hojŏk taejang), which are part of the major official documents compiled in ancient Korea. In the latter part of the Chosŏn dynasty (the 17th to 19th centuries), census registers were created every three years at the state level for the purpose of levying taxes. Therefore these registers contain information on the direct subjects of the state's governance. Generally, census registers contained information that heads of households reported to government offices about their family, but, depending on the need of the state, the government edited the census registers and selectively organized existing family members as a household. ${ }^{4}$ Through a closer examination of the household registers, we can explore how the Chosŏn government organized its citizens into households for the purpose of state governance.

Regrouping of the public in census registers mainly occurred as the basic units for tax collection purposes-households (ho, 戶) and individuals $(k u, \square)$. In the Chosón dynasty, a household was considered a tax unit, and taxes were levied on households, which consisted of family members as well as slaves belonging to the family, as well as on individual members of the household. While individuals were marked on census registers by the status of their service (職役), or their public duty to the state, the most important information about households were centered on the heads of households (juho, 主戶), who were responsible for paying

4 Sŏnggyun'gwandaehakkyo Taedongmunhwayŏn'guwŏn Hojŏktaejangyŏn'gut'im (Tansŏng Household Registration Study Group), Tansŏnghojǒktaejangyŏn'gu (A Study on Tansŏng Household Registration) (Seoul: Sŏnggyun'gwandaehakkyo Ch'ulp'anbu, 2003). 
the taxes. This means that heads of households in census registers were not necessarily actual heads of their households but rather tax bearers of the state. ${ }^{5}$ Records in census registers reveal that sometimes sons rather than fathers, who were actual heads of households, were listed as heads of households in census registers. In certain cases, second sons were listed heads of households rather than first sons. ${ }^{6}$ Women were no exceptionsometimes women were registered as heads of households. This goes to show that these female heads of households were not actual heads of households in patriarchal Korean society but were only recorded as heads of households in census registers for government purposes.

Research on female heads of households began only recently in Korean academia, and as a result not much has been revealed regarding these female heads of households. Moreover, the understanding of female heads of households is very different from that of male heads of households. One recent study argued that female heads of households in census registers symbolize the fact that women's social status was not low in the late Chosŏn dynasty, ${ }^{7}$ offering a directly conflicting perspective to the commonly held view that women's status declined in the late Chosŏn dynasty as patriarchy was reinforced. Despite this radical assertion, this study was still unable to extricate itself from the same methodology as previous related studies and discusses women's status within the framework of the

5 Kim Kuen-Tae, "Chosŏn-hugi Ho-ŭi Kujo-wa Hojŏng Unyŏng: Tansŏng Hojŏk-ŭl Chungshimuro (Organization of a family and its administration in the latter days of Kingdom Chosun: Contered on the family census register in Dansung County)," Taedongmunhwayŏn'gu 40 (June 2002).

6 Kim Kuen-Tae, "Hoguch'urip-ŭl T'onghae Bon 18-segi Hojŏkdaejang-ŭi P'yŏn'jebangshik: Tansŏng Hojŏkdaejang-ŭl Chungshimuro (Organization Method of Census Registers in the Eighteenth Century Seen Through Changing Members in Households: Focusing on Census Registers of Tansŏng County)," Taedongmunhwayŏn'gu 42 (June 2003).

7 Jung Ji Young, Chilssǒŭi Kuch'ukkwa Kyunyŏl: Chosŏnhugi Hojǒkkwa Yŏsŏngdŭl (The Construction of Order and Its Rupture: Household Registration and Women in Late Choson period) (Seoul: Sŏgangdaehakkyo Ch'ulp'anbu, 2015). 
family system. The main argument centers on the fact that male heads of households were men with the highest status in their families, and likewise female heads of households were women with the highest status in their families. Another existing study on female heads of households pointed out that a discussion of women's status in the late Chosŏn dynasty without enough background information could lead to a number of errors. It argued that it would be premature to discuss women's status without investigating the reasons why there were female heads of households in census registers as well as the nature of female heads of households, and proposed that female heads of households were primarily the result of the family register policy that was implemented in accordance with the state's tax collection system, and therefore does not directly reflect women's positions in the family order. ${ }^{8}$ This research result suggests that the role of female heads of households can help us understand the public role of women in relation to state policy in late Chosŏn.

Then why were some women listed as heads of households in census registers, which were official state documents, in late Chosŏn? In particular, what kind of public role did female heads of households play in relation to the state's governance activities? What is the significance of female heads of households in relation to women's social status at the time? These questions are the starting point for this study.

To this end, it is important to focus on how women were identified and defined in terms of tax purposes, which was a key factor in state administration in Chosŏn Korea. Changes have been detected in records of female heads of households, depending on the government's household policy as well as on the changing social status of women. The present study will analyze the circumstances in which female heads of households were listed in census registers and explore the ways in which the state defined women and addressed women in the private arena as well as the

8 Kim Kyungran, “Tansŏnghojŏge Nat'anan Yŏsŏngjuhoŭi Kijaesilt'aewa Sŏnggyŏk (The Record Status and Nature of the Female Family Heads seen in the Tansŏng Census Chart)," Yǒksawa Hyŏnshil 41 (September 2001). 
historical significance of female heads of households.

The historical sources analyzed in this paper are the census registers of Tansŏng county of Kyŏngsang province (Kyŏngsangdo Tansŏng hojŏk taejang), which was a typical farming county during the Chosŏn dynasty. ${ }^{9}$ Tansŏng was a small county in Kyŏngsang province with about 2,000 households since the eighteenth century according to the census registers. The registers were compiled every three years, and not all remain intact. The census registers that will be used for the purpose of this study are as follows: two census registers from the seventeenth century, 1606 and 1678, which are the oldest surviving census registers from this region; three registers from the eighteenth century, each from early, middle, and late eighteenth century $(1717,1759$, and 1783). As for resources from the nineteenth century, there are household registers that have been compiled by the administrative unit within Tansŏng county. For the purpose of this study, data from household registers for each county from the 1820 s and 1860s were collected and included in the statistics.

\section{Household Succession and Female Heads of Households}

In compiling household registers to determine the population of the country, the government of the Chosŏn dynasty established relationships of the members of a household based on the first name that was recorded on the list of household members. The lists generally began with the head of the household, followed by his wife, son(s), daughter(s), and nobi (slaves). The fact that the government determined the relationships of household members based on the name that was listed as the head of household is evidence of the high status that heads of households occupied at the time. The government considered heads of households important when creating census registers, as they had the responsibility to

9 “慶台道丹城縣戶籍大帳 (Census registers of Tansŏng county of Kyŏngsang province),” accessed May 1, 2018, http://ddmh.skku.edu/. 
pay taxes. When the taxes levied on households were not paid, their heads of households were punished. In an attempt to clarify the responsibility and accountability for taxes, the government systematized the format of recording information in census registers, in which the householder was listed as the representative of the household and the rest of the household members were described in relation to the householder. This regulation became mandated in the Chosŏn dynasty's code of law, the Kyŏngguk Taejŏn. ${ }^{10}$

The Chosŏn government wanted to maintain a certain number of households by region, and therefore hoped that households would not disappear. When there was a risk of the dissolution of a household due to the death, flight, or migration of the householder, commonly one member of the household became the successor to the householder title. As mentioned above, the very first name on the list of family members in the census registers was considered the householder. Therefore, when new heads of households were instituted, their names were written on the top of the list, and the members of the household were defined by their relationship to the new head of household. The most general recording format of a household in census registers when the existing householder was replaced is as follows:

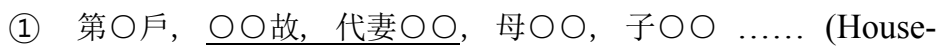
hold No. $\bigcirc$, Householder [name] Dead, Succeeded by Wife [name], Mother [name], Son [name], etc.)

(2) 第○戶, ○○故, 代子○○, 母 $\bigcirc$, 祖母 $\bigcirc \bigcirc \ldots . .$. (Household No. O, Householder [name] Dead, Succeeded by Son [name], Mother [name], Grandmother [name], etc.)

The above records show that the men who were recorded as heads of households in census registers died at some point in time within the three years before the next census was conducted. Type (1) record shows the

10 Kim Kuen-Tae, “Chosŏn-hugi Ho-ŭi Kujo-wa Hojŏng Unyŏng." 
wife of the original householder listed as the first of the family members after her husband's death, while type (2) record shows the son of the original householder listed as the first of the family members after his father's death. Considering that the first name on the list of family members was considered the head of the household, the succeeding head of household in the first record is the original householder's wife, while in the second record it is the original householder's son.

Here, it is important to consider the details of the type (1) household, where the head of household died and his wife's name appeared on the top of the list of family members (hereafter referred to as kodaech'o “ “故 代妻, meaning wife of the deceased" household), since Chosŏn Korea attempted to restrain households from having female heads of households. A legislation on census registers from the nineteenth century includes the following recommendation:

"Although a widow may oversee all domestic work, if she has an adult son, the son must be the head of the household." 11

According to the above legislation, even in the case of the death of her husband, who was the head of household, a woman was not able to succeed him as the head of household if there were other men of age in the family who could act as the head of household. This legislation implies that even if women were listed as the first in the list of family members as wives of the deceased, they might not necessarily be heads of households. In order to clarify this issue, the same households were examined in the census registers compiled in the succeeding census years to check who was listed as heads of households.

Table 1 shows the results of a review of census registers with kodaech'ó households. For this table, records of the same households with a

11 Kabosik Hojŏk Samok (甲午式戶籍事目), housed at Kyujanggak, Seoul National University, No. 12318. 
Table 1. Succeeding Heads of Households of Kodaech '̌̆ Households in Later Census Registers

\begin{tabular}{l|c|c|c|c}
\hline Head of the household in later census registers / Year & 1717 & 1729 & 1783 & 1786 \\
\hline Son & 5 & 3 & 1 & 0 \\
\hline Wife & 2 & 5 & 4 & 4 \\
\hline Dissolved households & 1 & 1 & 6 & 2 \\
\hline Others & 0 & 0 & 0 & $1^{* *}$ \\
\hline & 8 & 9 & 11 & 7 \\
\hline
\end{tabular}

* Among the existing census registers of Tansŏng county, ones that could be used to compare with the next census register have been compiled in 1717,1729, 1732, 1757, 1783, and 1786. For Table 1, census registers from the early and late eighteenth centuries, which are in good preserved conditions, were analyzed.

** Recorded as kodaech'ŏ households in later census registers.

son who was at least 16 years of age ${ }^{12}$ in later census registers were examined. The following information was gained from this table: first, the wife of the deceased does not necessarily succeed their husbands as head of household in kodaech'ó households. For instance, in the 1717 census register, there were eight kodaech' $\breve{o}$ households, where the head of household was deceased and the wife's name therefore appeared on the top of the list. Among them, five were recorded in the next census year (1720) with the son as the head of the household, while only two listed the wife of the deceased as the head of the household. What is important to note here is that of those two instances one household listed a son who was only 15 years old in 1717 as a member of the household, yet he became the succeeding head of household in 1729. The other household was dissolved in 1729 .

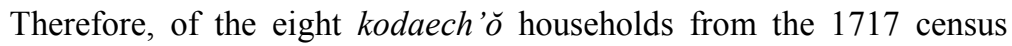
register, six were listed with the sons as succeeding heads of households in 1729. This shows that kodaech'ŏ households do not necessarily end up with female heads of households, and even when women do become

12 In this study, people 16 years or older were considered adults, as it was the age when compulsory military service began for men in the Chosŏn dynasty. 
heads of households, their status is only temporary until their sons come of age.

A different trend, however, appears in the late eighteenth century. The number of kodaech' $\breve{o}$ households from the 1783 and 1786 census registers, in which the wife of the deceased is recorded as the head of the household instead of their adult sons in the next census years, increases around this time. This shows that in an increasing number of instances, people did not abide by the law stipulating that adult sons rather than wives of the deceased should be listed as heads of households. I will explain this assertion in detail later.

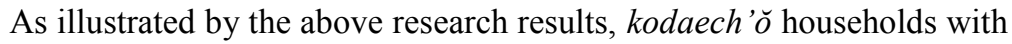
grown-up sons among family members listed the sons as heads of households according to law, while in some households the wife of the deceased was listed as the heads of households. Therefore, it is impossible to determine the head of household with only the records found in census registers. From this, we can estimate the method and the process in which women are decided to be heads of households. First, when the head of the household dies after a census was conducted, his death was reported to the government offices, and the household was recorded in the census register as a kodaech'ó household. Three years later, when the next census was conducted, the wife of the deceased was recorded as the head of household if there were no sons who were of age to be listed as a head of household. There are instances, however, in which the above rule was not followed. As a result, it is impossible to determine the actual head of household if a woman's name appears on the top of the list in kodaech'o households. Therefore, in this study, kodaech'ŏ households were treated separately and not included among households with female heads of households to avoid analytical errors. ${ }^{13}$

13 If we include the kodaech'o households, the percentage of female heads of households in late Chosŏn rise dramatically. Jung Ji Young included all of these households in female households in her analysis, concluding that the percentage of female heads of households in the latter half of the Chosŏn dynasty was very high 


\section{Records of Female Heads of Households}

In late Chosŏn dynasty, what percentage of households were headed by female heads of households? To answer this question, let us examine Table 2, which shows records of households with female heads of households from the early seventeenth century to the mid-nineteenth century. ${ }^{14}$

According to Table 2, the percentage of female heads of households varies by time frame. In the seventeenth century, female heads of households accounted for two to four percent of all households, while in the eighteenth century, the percentage of female heads of households rose to about three to ten percent. After the nineteenth century, the percentage of female heads of households decreased, hitting the one percent range in the mid-nineteenth century. While the percentage of female heads of households never exceeded 10 percent, male heads of households accounted for more or less 90 percent of all households in all census years. This shows that the status of the head of household was primarily given to men.

In the three East Asian countries, including Chosŏn Korea, China, and Japan, women were able to become heads of households only under limited circumstances. In China, women became heads of households when the whole house consisted of just one woman or had no son who was of age and could be registered as the head of household. In Japan, women were able to become the head of household (toshu, 當主) if she did not

and therefore women's social status was high during that time. Jung Ji Young, Chilssǒŭi Kuch'ukkwa Kyunyŏl.

14 Tansŏng County consisted of eight townships. However, parts of household registers from the nineteenth century are missing, and there is not a single census year where the information on all eight townships has been left intact. Therefore, for this study, household registers for the following townships that were compiled around the same time were used in addition to the Tansŏng County census register for analysis: (Early nineteenth century) 1825 (Pukdong and Odong), 1828 (Pŏmmurya, Shindŭng, Wŏndang, and Hyŏnnae), 1831 (Tosan and Saenbiryang). (Midnineteenth century) 1861 (Pŏmmurya and Shindŭng), 1864 (Pukdong, Odong, Wŏndang, and Hyŏnnae), 1867 (Tosan and Saenbiryang) 
Table 2. Gender Composition of Heads of households

\begin{tabular}{|c|c|c|c|c|c|c|c|}
\hline \multirow{2}{*}{ Year } & \multicolumn{2}{|c|}{$\begin{array}{c}\text { Male heads of house- } \\
\text { holds }\end{array}$} & \multicolumn{2}{|c|}{$\begin{array}{l}\text { Female heads of } \\
\text { households }\end{array}$} & \multicolumn{2}{|c|}{$\begin{array}{l}\text { Kodaech'ǒ heads of } \\
\text { households }\end{array}$} & \multirow{2}{*}{$\begin{array}{c}\text { Total } \\
\text { households }\end{array}$} \\
\hline & $\begin{array}{l}\text { Number of } \\
\text { households }\end{array}$ & $\begin{array}{c}\text { Percentage } \\
(\%)\end{array}$ & $\begin{array}{l}\text { Number of } \\
\text { households }\end{array}$ & $\begin{array}{c}\text { Percentage } \\
(\%)\end{array}$ & $\begin{array}{l}\text { Number of } \\
\text { households }\end{array}$ & $\begin{array}{c}\text { Percentage } \\
(\%)\end{array}$ & \\
\hline 1606 & 189 & $87 \%$ & 5 & $2 \%$ & 23 & $11 \%$ & 217 \\
\hline 1678 & 1880 & $89 \%$ & 86 & $4 \%$ & 152 & $7 \%$ & 2118 \\
\hline 1717 & 2360 & $94 \%$ & 98 & $4 \%$ & 60 & $2 \%$ & 2518 \\
\hline 1759 & 2130 & $89 \%$ & 262 & $10 \%$ & 32 & $1 \%$ & *2424 \\
\hline 1783 & 2835 & $94 \%$ & 143 & $5 \%$ & 25 & $1 \%$ & 3003 \\
\hline $\begin{array}{l}\text { Early } \\
19 \text { th } \\
\text { century }\end{array}$ & 3012 & $98 \%$ & 67 & $2 \%$ & 3 & . & 3082 \\
\hline $\begin{array}{l}\text { Mid- } \\
19 \text { th } \\
\text { century }\end{array}$ & 2605 & $99 \%$ & 26 & $1 \%$ & 1 & . & 2632 \\
\hline
\end{tabular}

* The source material is poorly preserved and therefore is missing data.

have a son who was of age or her son who was of age created trouble and was expelled from the village. ${ }^{15}$ Likewise, in Chosŏn Korea, only in rare circumstances were women able to become heads of households. As I mentioned above, in the late Chosonn dynasty, women were able to become heads of households only when there were no men of age among the members of the household.

As stated above, in East Asian countries, including Korea, women became heads of households only under limited circumstances. Then how did the Chosŏn dynasty classify female heads of households? How were the households with female heads of households recognized differently from households with male heads of households? To answer these questions, I have classified several characteristics found in the records of female heads of households in Table 3.

15 Kim Kyungran, “Tansŏnghojŏge Nat'anan Yŏsŏngjuhoŭi Kijaesilt'aewa Sŏnggyŏk." 
Table 3 illustrates that female heads of households were largely divided into three groups: widowed wives/women, commoner women, and slaves. Households with female heads of households are marked with social status, such as "yangnyŏ (commoner woman)" and "pi (slave woman, maid)," as well as their marital status, kwabu or kwanyo meaning widow. Such households are recorded as follows:

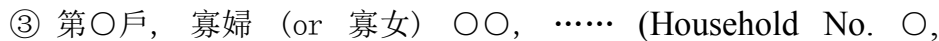
Kwabu or kwanyŏ (widowed wife/widowed) woman [name], etc.)

(4) 第○戶, 良女 (or 婢) $\bigcirc \bigcirc, \cdots . .$. (Household No. $\bigcirc$, Common woman/baseborn woman [name], etc.)

Table 3. Type of Households with Female Heads of Households

\begin{tabular}{|c|c|c|c|c|c|c|c|c|}
\hline $\begin{array}{c}\text { Year/ } \\
\text { Category }\end{array}$ & 1606 & 1678 & 1717 & 1759 & 1783 & 1786 & $\begin{array}{l}\text { Early } \\
19 \text { th } \\
\text { century }\end{array}$ & $\begin{array}{l}\text { Mid- } \\
19 \text { th } \\
\text { century }\end{array}$ \\
\hline $\begin{array}{l}\text { Widowed wife } \\
\text { household } \\
\text { (寡婦戶) }\end{array}$ & 0 & 0 & 14 & 50 & 43 & 41 & 22 & 6 \\
\hline $\begin{array}{l}\text { Widowed woman } \\
\text { household } \\
\text { (塞女戶) }\end{array}$ & 0 & 39 & 52 & 167 & 67 & 58 & 43 & 20 \\
\hline $\begin{array}{l}\text { Commoner wom- } \\
\text { an } \\
\text { household(良女戶) }\end{array}$ & & 11 & 5 & & 2 & 1 & 1 & \\
\hline $\begin{array}{l}\text { Slave household } \\
\text { (奴婢戶) }\end{array}$ & 5 & 35 & 21 & 32 & 14 & 3 & 1 & \\
\hline $\begin{array}{l}\text { No record of } \\
\text { social status } \\
\text { (職役無記) }\end{array}$ & & & & 13 & 12 & 15 & & \\
\hline Others & & 1 & 6 & & 5 & 1 & & \\
\hline Total & 5 & 86 & 98 & 262 & 143 & 119 & 67 & 26 \\
\hline
\end{tabular}


Type (4) is a record of households that mark the social status of the female heads of households who were commoners or slaves. Type (3), in comparison, does not mark the social status but marital status of the women households as widows. Interestingly, Table 4 shows that households with widowed women as the heads of households accounted for most of the households with female heads of households. Then what are the meanings of kwabu and kwanyo , and why did they account for most of the female heads of households?

Kwabu originally means "a woman whose husband is deceased." However, the records of kwabu and kwanyo for female heads of households in census registers do not refer to widows. There are actually a number of women whose status can be described as widows in census registersmother, sisters, or daughters of the head of the household. However, except for rare cases, terms such as " $k w a b u$ " do not appear next to the names of general members of households. Kwabu or kwanyo are only recorded next to the names of women who are listed as heads of households and continue to be listed as such in future census registers, as shown in Table 4.

Table 4. Status of Women Marked as Kwabu and Kwanyŏ in Household

\begin{tabular}{l|r|r|r|r|r|r|r}
\hline $\begin{array}{l}\text { Year } \\
\text { Status }\end{array}$ & 1606 & 1678 & 1717 & 1759 & 1783 & $\begin{array}{c}\text { Early 19th } \\
\text { century }\end{array}$ & $\begin{array}{c}\text { Mid-19th } \\
\text { century }\end{array}$ \\
$\begin{array}{l}\text { Head of } \\
\text { household }\end{array}$ & 39 & 66 & 217 & 110 & 65 & 26 \\
\hline Mother 母 & & 2 & 3 & 1 & & & \\
\hline Wife 婦 & & & 2 & & & 1 & \\
\hline Sister 妹 & & & 5 & 5 & 2 & 3 & 1 \\
\hline $\begin{array}{l}\text { Sister-in- } \\
\text { law 嫂 }\end{array}$ & & & & 1 & & & 2 \\
\hline Others & 0 & 41 & 56 & 224 & 112 & 69 & 29 \\
\hline Total & & & & & & & \\
\hline
\end{tabular}


Table 4 illustrates the status of women marked as kwabu and kwanyo within families. Most kwabu and kwanyo are recorded as heads of households, and only a small number of women who are the householder's mother, daughter-in-law, sister, and sister-in-law are recorded as kwabu or kwanyŏ. This shows that kwabu and kwanyo specifically refer to female heads of households and not all women who were widowed.

Another question that this conclusion raises is the reason why widowed female heads of households were divided into kwabu and kwanyŏ. First and last names were recorded on census registers for male heads of households. Contrary to this, women were recorded with certain appellations, such as ssi (氏), sŏng (姓), and sosa (召史). These appellations for women also varied by their social status. In census registers, the names of women of the elite class were followed by ssi (氏); names of middle class women were followed by sŏng (姓) or sosa (召史); and names of baseborn women were recorded without an appellation. ${ }^{16}$ A closer examination of the names of widows who were listed as heads of households show that most kwabu were marked with ssi, while as kwanyŏ were marked with sŏng or sosa. ${ }^{17}$ This shows that elite female heads of households were recorded as $k w a b u$, while commoner female heads of households were marked as kwanyŏ. Baseborn female heads of households mostly lacked the classification of kwabu or kwanyŏ.

The above information reveals that there are largely two characteristics in the records of female heads of households in the late Chosŏn dynasty. First, most female heads of households were widows without an adult man in the family. Second, female heads of households were grouped by their social status on census registers. Kwabu and kwanyŏ referred to elite and middle-class female heads of households, respectively, and female

16 Yi Chun'gu. “Chosŏn-hugi Yangbanshinbun Idong-e Kwanhan Yŏn'gu (sang) (A study on the social mobility of the yangban class in the second half of the Chosŏn dynasty, First)," Yǒksahakbo 96 (December 1982).

17 Kim Kyungran, 'Tansŏnghojŏge Nat'anan Yŏsŏngjuhoŭi Kijaesilt'aewa Sŏnggyŏk." 
heads of households who were yangnyŏ (commoner women) and pi (slave women) were sometimes marked by their social status. The fact that female heads of households were classified according to their social classes is an indicator that helps us understand the reason for their existence in the Chosŏn dynasty as well as their historical significance. The next section will delve deeper into this issue.

\section{Understanding the Background Information on Female Heads of Households and Their Status}

The Chosŏn dynasty levied taxes on households as well as on individuals. Therefore, counting the number of households was a basic necessity for state administration. In addition, the state's awareness of households shows the state's form of governance over the people. Then why were most female heads of households widows, and why were female heads of households recorded on census registers? And what kind of status did households headed by women occupy in the operation of tax schemes? But first, let us answer the queries proposed in the previous section and examine the government's perception of female heads of households.

The king said, "The royal regime must prioritize the care of widowers, widows, orphans, and people living alone. The Kaesŏng Magistracy's collecting taxes from households with widow heads of households is very regretful and lamentable. The Office of Border Defense should send an official document right away to stop magistrates from collecting taxes from households with widows as heads of households and beggars."18

The above source is an order from Hyojong, who was the king of

18 Pibyŏnsa Tüngnok (備邊司謄錄), June 23, in the fifth year in the reign of King Hyojong. 
Chosŏn in the mid-seventeenth century. It holds the most underprivileged people in Korean society-widowers, widows, orphans, and single-person households (鯀寡孤獨) — as people that the state needs to take care of in order to realize a virtuous- royal regime, which was pursued by the NeoConfucian state of Chosŏn. This order attests to the perception of the rulers that Confucian governance begins with providing the minimum foundation for such disadvantaged people to make a living, which included not imposing taxes on them. Based on this perception, households headed by widows were exempt from various duties to the state or eligible to receive relief.

In addition, widowers, widows, orphans, and single-person households were the primary beneficiaries of relief policy (賑恤政策). In Chosŏn Korea, relief policies were implemented when the base of the public's existence was under crisis due to massive famines or epidemics. The implementation of the policy involved the selection of beneficiaries, and one of the bases for selecting the beneficiaries of relief policies was households listed in census registers. Therefore, in the process of providing relief, the state first provided relief to those who were listed in census registers as widowers, widows, orphans, or single-person households. Those who were marked as widowers, widows, orphans, and single-person households were the first to receive relief and support. When such people were not marked as widowers, widows, orphans, and single-person households, the state conducted investigations to confirm their status, marked them as such in census registers, and allowed them to receive relief. ${ }^{19}$

Since households headed by widows were subject to receive state relief, the government had to distinguish them from regular households. Yet on the other hand, an increase in the number of households that were unable to pay their taxes was a burden on the state. The households listed in census registers were not uniform - they varied in nature. From the state's perspective, a household was an important tax unit, and as a result, households were largely divided into two groups: those that were able to

19 Pibyŏnsa Tüngnok, January 26, in the eighth year in the reign of King Chŏngjo. 
pay taxes and those that were not able to pay taxes. The former was marked as sirho (實戶), or wealthy households, while the latter was marked as hŏho (虛戶), or poor households. Widower, widow, orphan, or single-person households were not only subject to receive state relief but also mainly considered as poor households for the purpose of tax collection. ${ }^{20}$ Therefore in Chosŏn Korea, the state attempted to limit the number of such households in the process of counting them.

In the process of compiling census registers, the Chosŏn government created various books (Söngch'aek, 成冊) to effectively and completely profile individuals and households. A total of 29 books were created for Kabosik Hojŏk Samok (甲午式戶籍事目, Guide to compiling the household register in the kabo year). Not all of the books were completed, and the counties made necessary adjustments depending on their circumstances. ${ }^{21}$ One such book completed at the time was the book of Hwan'gwagodok households (䱊寡孤獨成冊). However, this book did not contain a list of Hwan'gwagodok households. Instead, it contained a fixed number of Hwan'gwagodok households for each county. Since the amount of taxes the government could collect decreased when the number of Hwan'gwagodok households increased, the state allocated the number of Hwan'gwagodok households for each county.

Yet, from the public's perspective, since widow households in census registers received tax relief, the tendency to violate the law increased.

20 Kim Kyungran, “'Tansŏnghyŏnhojŏktaejang'ŭi 'Yŏho' P'yŏnjebangsikkwa Ǔimi (Tansŏnghyŏn Method of Organizing the Yŏho in the Census Register and its Implications)," Han'guksa Yŏn'gu 126 (September 2004).

21 Kwon, Nae-Hyon, "Chosŏn-hugi Hojŏk-ŭi Chaksŏngkwajŏng-e Taehan Punsŏk (An analysis of the process of compiling familiy registers in the late Chosonn dynasty)," Taedongmunhwayŏn'gu 39 (December 2001). The Söngch'aek included information on the actual number of individuals in a household, their ages, move and escape, births and deaths, combination and separation of branches, new entries in household registers and dissolution of households, prevention of false accounts regarding public labor, economic conditions, and women's marriage. These Söngch'aek were used to better understand households as well as to collect taxes. 
Chŏng Yagyong, one of the Neo-Confucian reformists in the late eighteenth and early nineteenth centuries, harshly criticized the recording of female heads of households in census registers. He pointed out that when all women without husbands are widows, listing widows at the top of family members contained the intention to evade the burden placed on the household. ${ }^{22}$ Likewise, he also criticized households headed by hwanbu, or widowers.

As explained in detail above, households with female heads of households, who were generally widows, were primary relief beneficiaries of the state's ideological virtue-centered royal rule. Therefore, these households had to be counted in order for the state to provide the minimum base for livelihood to the public. Yet, at the same time, these households were considered poor households that were unable to pay the taxes, and so only a limited number of households were registered as such.

Another important characteristic of female heads of households is that they were classified by social class. The reason they were classified by class is an important indicator that helps us understand female heads of households.

Female heads of households changed across time depending on their social class. Social status in the Chosŏn dynasty can be largely divided into "gongmin (commoners)" and "nobi (baseborn)." Gongmin were expected to perform official public duty such as taking public office or serving in the military. Nobi on the other hand had no official duty to serve, but instead belonged to individuals or institutions that executed official duty and provided goods and services. Among gongmin, the elites who held public offices or prepared for the civil service exam to hold public offices were considered the upper class. The women of this upper class, the wives and daughters of the men who held public offices, also occu-

22 Chŏng Yagyong, “Hojŏn (戶典, household registry),” in “Hojŏkjo (戶籍條, provision on household registry)," Mongmin Simsŏ (牧民心書, a book for the mind of the shepherds of people). 
pied high status. $^{23}$

It is also important to note that although women's roles were limited to domestic labor and economic management of the household, female heads of households also performed official state duties as gongmin and heads of households. A closer examination at the distribution of female heads of households across social classes in Table 5 shows that pi (baseborn women) heads of households who provided goods and services to their owners accounted for 40 to 100 percent in the seventeenth century but decreased to 10 to 20 percent in the eighteenth century and only one percent in the nineteenth century. On the other hand, upper class female heads of households accounted for 20 percent of all female heads of households in the eighteenth century and exceeded 30 percent in the late eighteenth and early nineteenth centuries, when the overall number of female heads of households was decreasing.

Table 5. Class Distribution of Female Head of Household

\begin{tabular}{l|r|r|r|r|r|r|r}
\hline $\begin{array}{l}\text { Class } \\
\text { \Period }\end{array}$ & 1606 & 1678 & 1717 & 1759 & 1783 & $\begin{array}{c}\text { Early 19th } \\
\text { century }\end{array}$ & $\begin{array}{c}\text { Late 19th } \\
\text { century }\end{array}$ \\
\hline Elite & & & 14 & 50 & 43 & 22 & 6 \\
\hline Commoner & & 51 & 63 & 180 & 86 & 44 & 20 \\
\hline Baseborn & 5 & 35 & 21 & 32 & 14 & 1 & 0 \\
\hline Total & 5 & 86 & 98 & 262 & 143 & 67 & 26 \\
\hline Elite (\%) & & & $14 \%$ & $19 \%$ & $30 \%$ & $33 \%$ & $23 \%$ \\
\hline $\begin{array}{l}\text { Commoner } \\
(\%)\end{array}$ & $100 \%$ & $41 \%$ & $22 \%$ & $12 \%$ & $10 \%$ & $1 \%$ & $77 \%$ \\
\hline $\begin{array}{l}\text { Baseborn } \\
(\%)\end{array}$ & & $59 \%$ & $64 \%$ & $69 \%$ & $60 \%$ & $66 \%$ & \\
\hline
\end{tabular}

23 Kim Kyungran, “Chosŏnhugi Hojŏktaejangŭi Yŏsŏnghoch'ing Kyujŏnggwa Sŏnggyŏk: Tansŏnghojŏgŭl Chungsimŭro (The Regulations Regarding the Female Designations of the Chosonn dynasty's latter half period Census Registers, and the Nature of those Designations)," Yǒksawa Hyŏnshil 48 (June 2003). 
Then despite the state's attempt to contain the number of female heads of households, how was it possible for elite female heads of households to maintain their numbers? Here, it is important for us to recall the eighteenth century regulation (or a recommendation in reality) on household registration that "Although a widow may oversee all domestic work, if she has an adult son, the son must be the head of the household." This recommendation was proposed because the state intended to deter the creation of female heads of households, however, the reality reflects the actual status of women within the families. In other words, it was the widows who oversaw all affairs of their households in their deceased husbands' stead, even when they had sons who were married or of the age to be married.

In order to maintain the number of existing households, the state allowed households to have female heads of households temporarily until their sons came of age to serve their official state duties. Since military service applied to men between the ages of 16 and 60, men "of age" refers to sixteen-years-old or older. However, a closer examination of households with female heads of households shows that there were women who became heads of households even though they had sons who were sixteen years old or older. Let us look at Table 6 .

Table 6 shows that, in the early and mid-eighteenth century, female heads of households with 16-year-old or older sons accounted for 22 percent and 15 percent of all female heads of households, respectively. Interestingly, in the late eighteenth century, when the state begins to contain the number of female households, the percentage of female heads of households with 16-year-old or older sons begins to increase, reaching 36 percent of all female heads of households. This means that the number and proportion of female heads of households who began to ignore the state's recommendation to let grown sons succeed their deceased fathers as heads of households increased. Of course, there were cases in which adult sons were unable to immediately take on official state duty, and households with female heads of households were difficult to be maintained in the long term compared to general households. This means 
Table 6. Percentage of Female Heads of Households in Households with 16-YearOld or Older Sons (Unit: household, \%)

\begin{tabular}{l|c|r|r|r}
\hline \multicolumn{2}{c|}{ Category $\backslash$ Year } & 1717 & 1759 & \multicolumn{1}{c|}{1783} \\
\hline \multirow{2}{*}{$\begin{array}{l}\text { Female heads of } \\
\text { households in } \\
\text { households with }\end{array}$} & Elite & 10 & 12 & 23 \\
\cline { 2 - 5 } $\begin{array}{l}16 \text {-year-old or } \\
\text { older sons }\end{array}$ & Commoner & 8 & 25 & 26 \\
\cline { 2 - 5 } & Baseborn & 4 & 4 & 3 \\
\cline { 2 - 5 } $\begin{array}{l}\text { Percentage of } \\
\text { such households } \\
\text { among households } \\
\text { with women heads } \\
\text { of households ** }\end{array}$ & Commoner & $22 \%$ & $15 \%$ & $36 \%$ \\
\cline { 2 - 5 } & Baseborn & $12 \%$ & $14 \%$ & $54 \%$ \\
\hline
\end{tabular}

* Represents the percentage of female heads of households in households with 16-year-old or older sons among all female heads of households.

** Represents the percentage of female heads of households in households with 16-year-old or older sons by class.

that the fact that female heads of households occupied a provisional role cannot be denied.

It is interesting that this phenomenon was particularly strong among elite female heads of households. In all periods, among elite female heads of households, the percentage of female heads of households with 16year-old or older sons was much higher than other classes. There was a tendency among elite female heads of households with adult sons to maintain the householder position, which seems to reflect the fact that realistically elite women did not give up their position as the head of their families. In general, people have believed that, after the eighteenth century, elite families in Korean society began to strengthen the kinship bond based on the Neo-Confucian patriarchal hierarchy. However, this evidence raises a question regarding this perception.

The representative of a household has the responsibility to pay taxes and provide public labor service. This kind of official role did not have to be played by men. The state only expects a household to be basically made up of a married couple and their unmarried children, and sometimes 
includes relatives and non-blood related kin. Also, a household is expected to completely fulfill its duty to the state. Therefore, if one member of the householder couple were to die, the husband or wife left behind was recommended to hand over the position of head of household to the child who was to be married and be recorded as "mother" or "father."

The existence of female heads of households implies that women were able to singlehandedly fulfill the public duty to the state and that the state recognized their ability to do so. Also, the increase in the number of female heads of households until the mid-eighteenth century means that female heads of households were not simply temporary replacements until another male householder was instituted. And the phenomenon was also supported by the public's will to make women heads of households, because women played the role of head of household not only on census registers but also in reality but also due to the exemption and reduction of the burden of official state duty on heads of households who were widows.

However, households with female heads of households in census registers were often discontinued in the next census, which showed that it was difficult for female heads of households to avoid the temporariness of their status. And it is noteworthy that in the late eighteenth century and early nineteenth century, the number of female heads of households eventually decreases. ${ }^{24}$

24 Households with female heads of households tended to last for only a short amount of time. Among the 100 households with female heads of households in the 1729 census register, only 66 percent and 32 percent were recorded on the 1732 and 1735 census registers, respectively, while the rest were dissolved. Considering the fact that an average of 70 to 80 percent of households with male heads of households were found in the next years' census registers, households with female heads of households had a low rate of sustenance. Kim Kyungran, "Tansŏnghojŏge Nat'anan Yŏsŏngjuhoŭi Kijaesilt'aewa Sŏnggyŏk.” 


\section{Conclusion}

Women were considered to have been excluded from the public arena in traditional Korea. Accordingly, previous academic interest in women in Chosŏn was focused on the private sphere, within families. Contrary to this commonly held view, there were roles that women needed to play in state administration. Therefore the state granted a public role to women, which was realized in the form of women becoming the representatives of their own households.

Although the state only temporarily allowed women to become heads of households and attempted to deter women from becoming heads of households, the number of female heads of households actually grew from the seventeenth century to the mid-eighteenth century. As a result, female heads of households found on census registers during the time were temporary and limited in nature. However, it is important not to neglect that women's public roles granted by the state, whether it is because in reality women have higher status in families, or because households wish to avoid the public responsibility of the state, is important. This also means that we need to reconsider the social and public status of women from traditional Korea, which is considered a repressive and dark period for women.

Moreover, female heads of households were more repressed in the late eighteenth century, which is considered the time of discovery of the "sprouts" of industrialization in Korea - the point in which modern transformation began and caused confusion. The state's attempt to contain the number of female heads of households and the traditional method of addressing them are an aspect of the modern transformation of Korean society, and it prompts us to revisit the idea of gender in modern Korea. It is possible to propose that state regulation on women becomes stronger the more modern society becomes.

At this point, it would be important to review how strong the state regulations were for women and to examine whether women really served the role of the "breadwinner" in the family and acquired social status. 
Further studies should be conducted to restore families in census registers and examine the status of women in those families who were elderly or widowed.

\section{References}

1. Deuchler, Martina. The Confucian Transformation of Korea: A Study of Society and Ideology. Cambridge: Harvard University Press, 1992.

2. Jung, Ji Young. Chilssǒŭi Kuch'ukkwa Kyunyŏl: Chosŏnhugi Hojŏkkwa Yŏsŏngdŭl (The Construction of Order and Its Rupture: Household Registration and Women in Late Choson period). Seoul: Sŏgangdaehakkyo Ch'ulp'anbu, 2015.

3. Kim, Kuen-Tae. "Chosŏn-hugi Ho-ŭi Kujo-wa Hojŏng Unyŏng: Tansŏng Hojŏk-ŭl Chungshimŭro (Organization of a family and its administration in the latter days of Kingdom Chosun: Contered on the family census register in Dansung County)." Taedongmunhwayŏn'gu 40 (June 2002): 217-61.

4. Kim, Kuen-Tae. 'Hoguch'urip-ŭl T’onghae Bon 18-segi Hojŏkdaejang-ŭi P'yŏn'jebangshik: Tansŏng Hojŏkdaejang-ŭl Chungshimuro (Organization Method of Census Registers in the Eighteenth Century Seen Through Changing Members in Households: Focusing on Census Registers of Tansŏng County)." Taedongmunhwayŏn'gu 42 (June 2003): 171-208.

5. Kim, Kyungran. "Tansŏnghojŏge Nat'anan Yŏsŏngjuhoŭi Kijaesilt'aewa Sŏnggyŏk (The Record Status and Nature of the Female Family Heads seen in the Tansŏng Census Chart)." Yǒksawa Hyŏnshil 41 (September 2001): 94-119.

6. Kim, Kyungran. "Chosŏnhugi Hojŏktaejangŭi Yŏsŏnghoch'ing Kyujŏnggwa Sŏnggyŏk: Tansŏnghojŏgŭl Chungsimŭro (The Regulations Regarding the Female Designations of the Chosŏn dynasty's latter half period Census Registers, and the Nature of those Designations)." Yǒksawa Hyŏnshil 48 (June 2003): 191-219.

7. Kim, Kyungran. “'Tansŏnghyŏnhojŏktaejang'ŭi 'Yŏho' 
P'yŏnjebangsikkwa Ǔimi (Tansŏnghyŏn Method of Organizing the Yŏho in the Census Register and its Implications)." Han'guksa Yŏn'gu 126 (September 2004): 151-76.

8. Kwon, Nae-Hyon. "Chosŏn-hugi Hojŏk-ŭi Chaksŏngkwajŏng-e Taehan Punsŏk (An analysis of the process of compiling familiy registers in the late Chosŏn dynasty)." Taedongmunhwayŏn'gu 39 (December 2001): 63-95.

9. Lee, Soon-Gu. "Chosŏnch'ogi Chongbŏbŭi Suyonggwa Yŏsŏngjiwiŭi Pyŏnhwa (Propagation of the Chong-pop and Changes in the Status of Women during the early Chosŏn Dynasty)." $\mathrm{PhD}$ diss., Academy of Korean Studies, 1995.

10. Lee, Soon-Gu and Han, Heesook. "Chosŏn-sidae Yŏsŏngsa Kwallyŏn Yŏn'gu-ŭi Hyŏhwang-gwa Kwaje (The Current Status and Issues in Studies on Women in the Chosŏn Dynasty)." In Such'on Pak Yŏng-sŏk Kyosu Hwagap Kinyŏm Han'guksahangnonch'ong 1, edited by Such'on Pagyŏngsŏk Kyosu Hwagap Kinyŏm Nonch'ongganhaengwiwŏnhoe, Seoul: T’amgudang, 1992.

11. Peterson, Mark A. Korean Adoption and Inheritance: Case Studies in the Creation of a Classic Confucian Society. Ithaca: East Asian Program Cornell University, 2000.

12. Sŏnggyun'gwandaehakkyo Taedongmunhwayŏn'guwŏn Hojŏktaejangyŏn'gut'im (Tansŏng Household Registration Study Group). Tansŏnghojǒktaejangyŏn'gu (A Study on Tansŏng Household Registration). Seoul: Sŏnggyun'gwandaehakkyo Ch'ulp'anbu, 2003.

13. Yi, Chun'gu. "Chosŏn-hugi Yangbanshinbun Idong-e Kwanhan Yŏn'gu (sang) (A study on the social mobility of the yangban class in the second half of the Chosŏn dynasty, First)." Yǒksahakbo 96 (December 1982): 139-84. 


\section{Female Heads of Households Registered in Korea's Census Registers Between the Seventeenth and Nine- teenth Centuries and Their Historical Significance}

Generally, women in traditional Korea were thought to have been excluded from the public arena of the state. However, such perception is based on a stereotype that women were confined to the private arena within families. In fact, parts of state administration in Chosŏn Korea required women's participation. The state granted women public roles, one of which was allowing them to be heads of households.

Female heads of households, who were mostly widow heads of households ( $k$ wabuho, 葟婦戶), were primary beneficiaries of the state's relief policies under the ideology of virtue-centered royal regime. Therefore the state took a count of these female heads of households in order to provide the basic needs for their livelihood. However, since most of these households were poor and could not pay taxes, their existence threatened the state's finances. Because of this, the Chosorn government only granted temporary householder positions to women and attempted to contain their number.

As this study illustrates, female heads of households in census registers were temporary and limited in nature. Women were able to become heads of households because sometimes they occupied higher status in their families or because they tried to avoid the public burden placed on their household. Regardless of the reason, however, it is important to note that women did fulfill important public roles for the state as heads of households. This evidence suggests the need to reexamine the status of women in traditional Korean society, who have been considered to be oppressed and living in the dark ages.

Keywords: householder, census registers, widows, relief, social status 


\section{〈국문초록〉}

\section{19세기 한국의 호적대장에 등재된 女性圭戸와 그 역사적 의미}

일반적으로 한국의 전통시대 여성은 국가의 公的 영역에서 배제된 것으로 이해 되고 있다. 그러나 이러한 인식은 선험적인 것이며, 국가의 운영상 여성의 역할이 필요한 부분이 존재하였다. 이에 따라 국가에서는 여성에게 公的인 역할을 부여하 고자 하였고, 대표적인 것이 여성이 戶의 대표자인 主戶가 되었다는 사실이다.

주로 ‘寡婦戶’로 파악되었던 여성주호는 ‘王政’이라는 이념적 측면에서 국가의 일차적 진휼대상이었다. 따라서 이들에 대한 파악은 民의 최소한의 존립기반을 마 련해 주어야 한다는 입장에서 이루어졌다. 하지만 이들은 賦税 부담을 할 수 없는 虛戶였기 때문에 국가의 재정이 악화될 우려가 있었다. 이 때문에 조선 정부는 여 성이 호의 대표자로 서는 것을 어쩔 수 없는 임시적 조치로 설정하고, 그것을 억 제하고자 했다.

이와 같이 여성주호는 戶籍上에 임시적이고 제한적 성격을 가지고 있었으나, 한 편으로 그것이 현실적으로 가족 가운데 여성이 가지는 지위가 높기 때문이든, 국 가의 공적인 부담을 회피하기 위해서든, 국가에 대한 여성의 공적 역할이 증대한 측면을 무시할 수 없다. 이 사실은 억압되어 암흑의 시대를 산다고 여겨지기도 한 전통사회 여성의 사회적, 국가적 위상에 대해 再考해야 함을 의미한다.

주제어: 主戶, 호적대장, 과부, 진휼, 계층 